\title{
KUAT LENTUR PANEL DINDING BETON BUSA DENGAN LAPIS GRC DAN WIREMESH
}

\author{
Lilis Tiyani ${ }^{1}$, Iman Satyarno ${ }^{2}$, Ashar Saputra ${ }^{3}$ \\ ${ }^{1}$ Department Teknik Sipil dan Lingkungan, Universitas Gadjah Mada, Yogyakarta \\ Email: lilis.tiyani@mail.ugm.ac.id \\ ${ }^{2}$ Department Teknik Sipil dan Lingkungan, Universitas Gadjah Mada, Yogyakarta \\ Email: imansatyarno@ugm.ac.id \\ ${ }^{3}$ Department Teknik Sipil dan Lingkungan, Universitas Gadjah Mada, Yogyakarta \\ Email: saputra@ugm.ac.id
}

\begin{abstract}
The demand for lightweight concrete has been rising as this material is lighter in weight, making the load in the structure smaller. The lightweight used in this research was made from a mixture of water, cement, sand and foam. Besides the lighter smaller specific gravity, designing this lightweight foam concrete with compressive strength that is equivalent to the wall concrete commonly used of around 3-5 Mpa was also the target of this research. Unfortunately, foam concrete has weak tensile strength that it would withstand the vertical force of the wall when it is used for wall panel. This research was conducted to analyze the flexural strength and the shear strength of wall panel with GRC outer layer and wiremesh reinforcement. The test of flexural strength and shear strength employed wall panel of $50 \mathrm{~mm}$ think, $400 \mathrm{~mm}$ wide and 800 $\mathrm{mm}$ long. This test resulted in modulus elasticity value of 6856,6 $\mathrm{MPa}$, compressive strength of 5,2 MPa and tensile strength of 0,7 MPa. The flexural strength of wall panel without GRC outer layer and without wiremesh reinforcement was found at 1,5 MPa. Meanwhile, the flexural strength of the wall panel with GRC outer layer without wiremesh reinforcement was found at 4,6 MPa. Finally, the wall panel applied with GRC outer layer and wiremesh reinforcement showed a flexural strength 5,3 $\mathrm{MPa}$.
\end{abstract}

Keywords: foam concrete, GRC, wiremesh, flexural strength

\section{PENDAHULUAN}

\section{Latar Belakang}

Ketertarikan masyarakat menggunakan beton sebagai komponen struktur menimbulkan banyak jenis dari beton itu sendiri, salah satunya yang sedang dikembangkan yaitu beton ringan. Beton ringan banyak diminati karena berat jenisnya yang ringan, sehingga beban yang bekerja pada struktur menjadi lebih kecil. Beton ringan mempunyai berat kurang dari $1800 \mathrm{~kg} / \mathrm{m}^{3}$ (Tjokrodimuljo, 2007). Beton busa dalam penelitian ini dibuat dengan campuran air, semen, pasir dan busa. Penambahan busa pada campuran akan membentuk pori-pori pada beton, sehingga beton tersebut menjadi ringan karena berkurangnya jumlah material yang digunakan. Busa di sini dibentuk dari foaming agent yang dicampur dengan air yang akan menghasilkan busa yang stabil. Foaming agent dipilih sebagai bahan pembentuk pori karena mudah didapat dan mudah diproduksi secara masal.

Menurut Satyarno (2015), beton berongga biasa disebut dengan aerated concrete atau lebih terkenal dengan istilah foamed concrete adalah beton dengan kandungan udara atau rongga yang banyak di dalam beton. Tujuan membuat beton berongga mirip dengan beton non-pasir. Rongga-rongga pada beton nonpasir didapat karena tidak adanya pasir dalam campuran beton. Sebaliknya beton berongga dibuat tanpa menggunakan kerikil dimana rongga-rongga yang banyak di dalamnya dibuat dengan menggunakan 
bahan foaming agent yang dapat membuat gelembung-gelembung udara menyerupai busa dalam beton.

Selain berat jenis yang lebih ringan, target yang ingin dicapai dalam perancangan beton busa ini adalah nilai kuat tekan yang setara dengan bahan penyusun dinding yang umumnya digunakan yaitu 3 s.d. $5 \mathrm{MPa}$. Akan tetapi beton busa mempunyai kuat tarik rendah, sehingga apabila digunakan pada panel dinding akan lemah menahan gaya arah tegak lurus dinding. Untuk mendapatkan beton busa dengan kuat tekan yang tinggi dapat dilakukan dengan menurunkan faktor air semen dalam campuran beton. Akan tetapi hal ini dapat menyebabkan beton semakin sulit dalam pengerjaannya. Oleh karena itu dibutuhkan adanya bahan tambah yaitu superplasticizer dalam campuran adukan beton yang berfungsi untuk mempermudah dalam pengerjaan beton serta menurunkan kebutuhan penggunaan air, sehingga kuat tekan yang diharapkan dapat tercapai.

Menurut Putra (2017), dinding merupakan salah satu elemen bangunan yang berfungsi memisahkan/membentuk ruang. Ditinjau dari segi struktur dan konstruksi, dinding ada yang berupa dinding partisi/pengisi (tidak menahan beban) dan ada yang berupa dinding struktural (bearing wall).

Menurut Abduh (2007), beton pracetak adalah teknologi konstruksi struktur beton dengan komponen-komponen penyusun yang dicetak terlebih dahulu pada suatu tempat khusus (off site fabrication), terkadang komponen-komponen tersebut disusun dan disatukan terlebih dahulu (pre-assembly), dan selanjutnya dipasang di lokasi (installation), dengan demikian sistem pracetak ini akan berbeda dengan konstruksi monolit terutama pada aspek perencanaan yang tergantung atau ditentukan pula oleh metoda pelaksanaan dari pabrikasi, penyatuan dan pemasangannya, serta ditentukan pula oleh teknis perilaku sistem pracetak dalam hal cara penyambungan antar komponen join.

Manfaat yang diharapkan dari penelitian ini adalah diharapkan dapat tercapainya kebutuhan dinding alternatif agar tercapainya pemenuhan kebutuhan pembangunan.

\section{METODE PENELITIAN}

Tahapan kegiatan yang dilakukan dalam penelitian ini meliputi:

\section{Tahap Persiapan}

Pada tahap ini dilakukan persiapan terhadap bahan dan peralatan yang akan digunakan, antara lain pemeriksaan peralatan yang akan digunakan, pemeriksaan agregat halus yang akan digunakan, pemeriksaan secara visual terhadap semen yang akan digunakan, pemeriksaan kondisi air yang ada di Laboratorium Bahan Bangunan.

\section{Tahap Pemeriksaan Bahan}

Pemeriksaan yang dilakukan meliputi pemeriksaan pasir, pemeriksaan semen, pemeriksaan air, dan pemeriksaan foaming agent.

\section{Tahap Perancangan Campuran (Mix Design)}

Pada tahap ini dilakukan perancangan campuran terhadap bahan yang akan digunakan, antara lain jenis semen ditetapkan yaitu Semen Gresik jenis PCC, agrepat halus yang digunakan adalah pasir dengan diameter butir seragam yaitu lolos ayakan 6 $\mathrm{mm}$ dan tertahan pada ayakan $3 \mathrm{~mm}$, penetapan nilai faktor air semen (FAS) yaitu 0,3 untuk memperkecil kemungkinan terbentuknya rongga yang disebabkan oleh terjadinya penguapan air sisa hidrasi semen, penetapan perbandingan volume semen : pasir yaitu 1 : 1,25, penentuan kadar superplasticizer yang digunakan dalam campuran berdasarkan hasil uji coba didapatkan kadar superplasticizer optimum yaitu dengan variasi perbandingan semen : 
pasir yaitu 1 : 1,25 dengan SP $0,8 \%$ (6) menghitung berat bahan penyusun beton.

Jumlah foaming agent yang harus ditambahkan pada beton tergantung dari berat rencana yang ditetapkan.

Perancangan campuran beton busa dihitung berdasarkan volume absolut material dengan menentukan faktor air semen (FAS) dan perbandingan volume semen : pasir menggunakan persamaan volume absolut berikut ini.

$$
\frac{V_{c} \gamma_{c}}{G_{c} \gamma_{w}}+\frac{V_{s} \gamma_{s}}{G_{s} \gamma_{w}}+\frac{V_{w} \gamma_{w}}{G_{w} \gamma_{w}}+\frac{V_{s p} \gamma_{s p}}{G_{s p} \gamma_{w}}=1
$$

dengan $G_{c}=$ berat jenis semen, $G_{s}=$ berat jenis pasir, $G_{w}=$ berat jenis air, $G_{s p}=$ berat jenis superplasticizer, $\gamma_{c}=$ berat satuan semen, $\gamma_{s}=$ berat satuan pasir, $\gamma_{w}=$ berat satuan air, $\gamma_{s p}=$ berat satuan superplasticizer.

Jika faktor air semen (FAS) dan perbandingan volume semen : pasir ditentukan maka persamaan menjadi:

$\frac{V_{c} \gamma_{c}}{G_{c} \gamma_{w}}+\frac{s V_{c} \gamma_{s}}{G_{s} \gamma_{w}}+\frac{w / c V_{c} \gamma_{c}}{G_{w} \gamma_{w}}+\frac{s p V_{c} \gamma_{c}}{G_{s p} \gamma_{w}}=1$

dengan $s=$ perbandingan volume semen, $w / c=$ faktor air semen (FAS), $s p=$ persentase superplasticizer. Menggunakan persamaan (1) dan (2) maka kebutuhan volume semen per $\mathrm{m}^{3}$ dapat dihitung dan kebutuhan material lain juga dapat dihitung.

Tabel 1 Kebutuhan bahan penyusun beton busa per $\mathrm{m}^{3}$

\begin{tabular}{|c|c|c|}
\hline \multirow{2}{*}{ Perbandingan Volume } & Semen : Pasir & $1: 1,25$ \\
\hline \multirow{3}{*}{$\begin{array}{c}\text { Kebutuhan Bahan per } \\
\mathrm{m}^{3}\end{array}$} & Semen $(\mathrm{kg})$ & 297,17 \\
\cline { 2 - 3 } & Pasir $(\mathrm{kg})$ & 411,30 \\
\cline { 2 - 3 } & Air $(\mathrm{kg})$ & 89,15 \\
\cline { 2 - 3 } & $\mathrm{SP}(\mathrm{kg})$ & 2,38 \\
\cline { 2 - 3 } & Busa $(\mathrm{kg})$ & 4,97 \\
\hline Berat Jenis & \multicolumn{2}{|c|}{1,00} \\
\hline
\end{tabular}

\section{Tahap Pengujian Benda Uji}

\section{Pengujian tekan}

Pengujian tekan mortar dilakukan dengan benda uji berbentuk kubus berukuran $5 \mathrm{~cm} \mathrm{x}$ $5 \mathrm{~cm} \times 5 \mathrm{~cm}$. Sebelum dilakukan pengujian, dihitung lebar dan tebal benda uji. Benda uji dipasang pada mesin uji tekan lalu dilaksakan pengujian hingga benda uji patah atau retak.

\section{Pengujian modulus elastisitas mortar}

Pengujian untuk mengetahui modulus elastisitas mortar menurut SNI 03-41691996. Pengujian menggunakan benda uji berbentuk silinder dengan diameter $150 \mathrm{~mm}$ dan tinggi $300 \mathrm{~mm}$ sebagaimana Gambar 1 . Langkah yang dilakukan untuk pengujian mortar adalah sebagai berikut.

a. Mengukur dimensi benda uji.

b. Memberikan lapisan perata pada permukaan benda uji

c. Meletakkan benda uji pada mesin uji tekan.

d. Memasang penolok untuk mengukur defleksi yang terjadi saat dilakukan pembebanan.

e. Pembebanan dilakukan dengan kecepatan pembebanan sekitar 0,075 MPa per-detik.

f. Pembebanan dilakukan hingga benda uji mengalami keruntuhan.

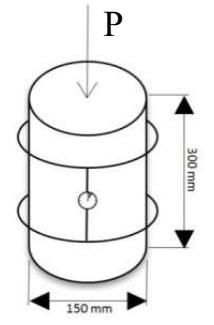

Gambar 1. Uji modulus elastisitas mortar

\section{Pengujian kuat tarik mortar}

Pengujian tarik mortar dilakukan dengan benda uji berbentuk cat bone. Sebelum dilakukan pengujian, dihitung lebar dan tebal benda uji. Benda uji dipasang pada mesin uji tarik lalu dilaksakan pengujian hingga benda uji patah atau retak. 


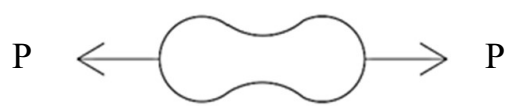

Gambar 2. Uji tarik mortar

4. Pengujian Kuat Lentur Panel Dinding

Berdasarkann ASTM E72-05 diketahui bahwa kekuatan lentur panel diuji menggunakan metode uji dua titik beban. Dengan benda uji berukuran $80 \mathrm{~cm}$ x $40 \mathrm{~cm}$ $\mathrm{x} 5 \mathrm{~cm}$. Pengujian dilakukan dengan memberikan dua tumpuan diujung panel, dan beban dikenakan pada seper tiga lebar panel.

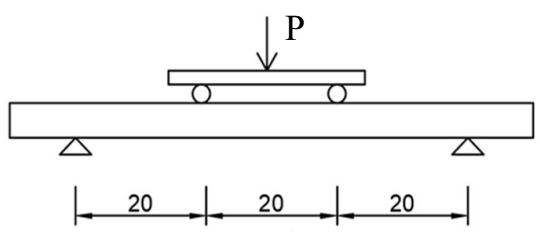

Gambar 3. Pengujian kuat lentur panel

\section{Pengujian Kuat Geser Panel Dinding}

Pengujian geser panel dilakukan dengan benda uji berukuran $80 \mathrm{~cm} \times 40 \mathrm{~cm} \times 5 \mathrm{~cm}$. Pengujian ini dengan meletakkan dinding searah tegak horizontal lalu diberikan beban pada tengah dinding hingga panel mengalami kegagalan.

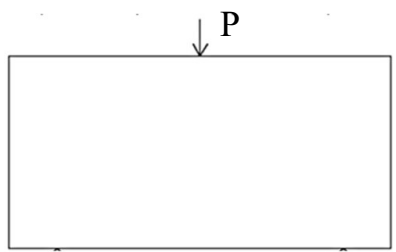

Gambar 4. Pengujian kuat geser panel

\section{Tahap Pembuatan Benda Uji}

Jumlah benda uji silinder dengan ukuran diameter $150 \mathrm{~mm} \times$ tinggi $300 \mathrm{~mm}$ untuk pengujian modulus elastisitas umur 28 hari, benda uji berbentuk kubus ukuran $5 \mathrm{~cm}$ x 5 $\mathrm{cm} \times 5 \mathrm{~cm}$ untuk pengujian kuat tekan kubus dan catbone untuk pengujian kuat tarik umur 28 hari masing-masing sebanyak 3 buah untuk tiap-tiap variasi. Jumlah benda uji panel dinding dengan tebal $50 \mathrm{~mm}$ lebar 400 $\mathrm{mm}$ dan panjang $800 \mathrm{~mm}$ untuk pengujian kuat lentur dan kuat geser.

Sketsa benda uji panel dinding

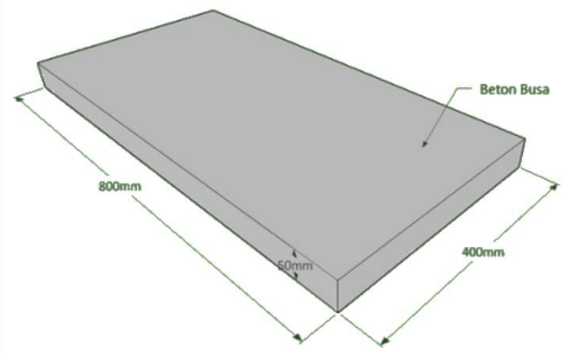

Gambar 5. Panel dinding variasi (1)

Gambar 5 menunjukkan panel dinding beton busa yang dibuat tanpa menggunakan lapis GRC dan perkuatan wiremesh.

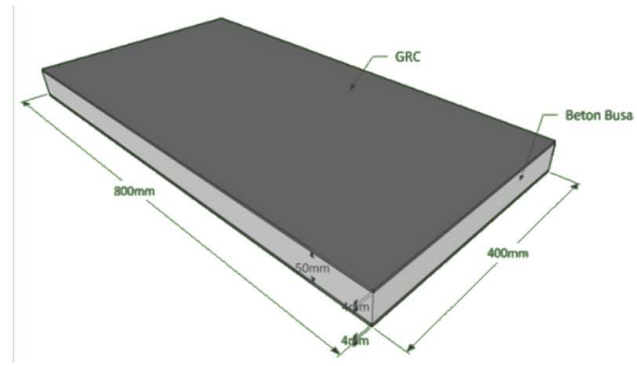

Gambar 6. Panel dinding variasi (2)

Gambar 6 menunjukkan panel dinding yang dibuat dengan pelapis luar GRC pada bagian atas dan bawah panel dinding, dengan bagian tengah merupakan beton busa dan tanpa diberi perkuatan wiremesh.

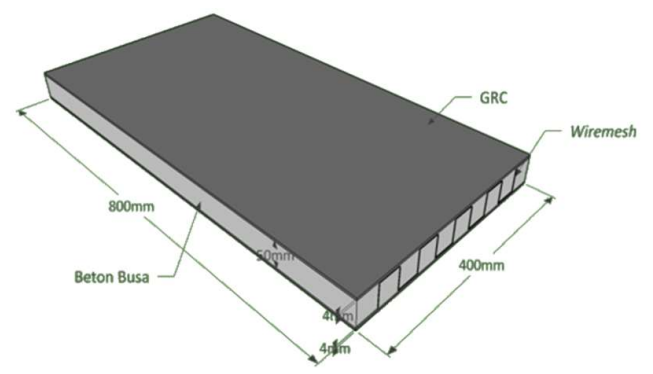

Gambar 7. Panel dinding variasi (3)

Gambar 7 menunjukkan panel dinding yang dibuat dengan pelapis luar GRC pada bagian atas dan bawah panel dinding, dengan bagian 
tengah merupakan beton busa yang diberi perkuatan wiremesh yang dibentuk corrugated persegi.

\section{Tahap Analisis Data dan Pembahasan}

a. Melakukan input data.

b. Mencatat semua hasil pengujian baik pengujian fisik, mekanik.

c. Menganalisis dan mengolah data.

d. Data hasil pengujian diolah, dianalisa dan disajikan dalam bentuk tabel dan grafik.

e. Penentuan benda uji sesuai persyaratan.

f. Menentukan benda uji yang paling optimal dan memenuhi persyaratan, berdasarkan hasil pengujian yang telah dilaksanakan.

\section{HASIL DAN PEMBAHASAN}

\section{Pengujian Kuat Tekan Beton Busa}

Pengujian kuat tekan pada penelitian ini menggunakan standar SNI - 03-6825-2002, benda uji berbentuk kubus dengan ukuran 5 $\mathrm{cm} \times 5 \mathrm{~cm} \times 5 \mathrm{~cm}$ sebanyak 3 buah benda uji dan pengujian dilakukan pada umur 28 hari. Hasil pengujian kuat tekan rerata beton busa umur 28 hari dapat dilihat pada Tabel 2.

Tabel 2. Kuat tekan rerata benda uji umur 28 (hari)

\begin{tabular}{|c|c|}
\hline $\begin{array}{c}\text { Perbandingan } \\
\text { Volume }\end{array}$ & Kuat Tekan (MPa) \\
\hline Semen : Pasir & 28 hari \\
\hline $1: 1,25$ & 5,2 \\
\hline
\end{tabular}

\section{Pengujian Kuat Tarik Beton Busa}

Pengujian kuat tarik pada penelitian ini menggunakan standar ASTM C 307 - 03, benda uji berbentuk catbone sebanyak 3 buah benda uji dan pengujian dilakukan pada umur 28 hari. Hasil pengujian kuat tarik rerata beton busa umur 28 hari dapat dilihat pada Tabel 3.
Tabel 3. Kuat tarik rerata benda uji umur 28 (hari)

\begin{tabular}{|c|c|}
\hline $\begin{array}{c}\text { Perbandingan } \\
\text { Volume }\end{array}$ & Kuat Tarik (MPa) \\
\hline Semen : Pasir & 28 hari \\
\hline $1: 1,25$ & 0,7 \\
\hline
\end{tabular}

\section{Modulus Elastisitas Beton Ringan}

Pada penelitian ini pengujian modulus elastisitas dilakukan dengan menggunakan alat CTM (Compression Testing Machine) dengan benda uji silinder beton terpasang dial gauge untuk mengukur perpendekan pada beton. Perhitungan nilai modulus elastisitas menggunakan perbandingan grafik tegangan regangan beton ringan. Hasil pengujian modulus elastisitas beton ditampilkan pada Tabel 4.

Tabel 4. Modulus elastisitas beton ringan

\begin{tabular}{|c|c|c|}
\hline $\begin{array}{c}\text { Kode } \\
\text { Benda Uji }\end{array}$ & $\begin{array}{c}\text { Modulus Elastisitas } \\
\text { (MPa) }\end{array}$ & $\begin{array}{c}\text { Rerata } \\
\text { (MPa) }\end{array}$ \\
\hline B1 & 5658,8 & \\
B2 & 7748,9 & 6856,6 \\
B3 & 7161,9 & \\
\hline
\end{tabular}

\section{Dimensi dan Berat Panel Dinding}

Pengukuran dimensi dan berat benda uji panel dinding dilakukan sebelum pengujian kuat lentur dan kuat geser. Hasil pengujian dimensi dan berat benda uji panel dinding dapat dilihat pada Tabel 5, Tabel 6, dan Tabel 7.

Tabel 5. Dimensi panel dinding

\begin{tabular}{|c|c|c|c|}
\hline \multirow{2}{*}{$\begin{array}{c}\text { Variasi Panel } \\
\text { Dinding }\end{array}$} & $\begin{array}{c}\text { Danjang } \\
(\mathrm{mm})\end{array}$ & $\begin{array}{c}\text { Lebar } \\
(\mathrm{mm})\end{array}$ & $\begin{array}{c}\text { Tebal } \\
(\mathrm{mm})\end{array}$ \\
\cline { 2 - 4 } & 800 & 400 & 50 \\
\hline $\begin{array}{c}\text { Tanpa Lapis } \\
\text { GRC }\end{array}$ & 800 & 400 & 42 \\
\hline $\begin{array}{c}\text { Pelapis Luar } \\
\text { GRC }\end{array}$ & 800 & 400 & 42 \\
\hline $\begin{array}{c}\text { Pelapis Luar } \\
\text { GRC dan } \\
\text { Perkuatan } \\
\text { Wiremesh }\end{array}$ & & & \\
\hline
\end{tabular}


Tabel 6. Dimensi GRC yang digunakan untuk panel dinding

\begin{tabular}{|c|c|c|c|c|}
\hline \multirow[b]{2}{*}{$\begin{array}{l}\text { Variasi } \\
\text { Panel } \\
\text { Dinding }\end{array}$} & \multicolumn{3}{|c|}{ Dimensi GRC } & \multirow[b]{2}{*}{$\begin{array}{c}\text { Berat } \\
\text { GRC (2 } \\
\text { GRC) } \\
\text { (kg) }\end{array}$} \\
\hline & $\begin{array}{r}\text { Panjang } \\
\text { (mm) }\end{array}$ & $\begin{array}{l}\text { Lebar } \\
(\mathrm{mm})\end{array}$ & $\begin{array}{c}\text { Tebal (2 } \\
\text { GRC) } \\
(\mathrm{mm})\end{array}$ & \\
\hline $\begin{array}{l}\text { Tanpa } \\
\text { Lapis } \\
\text { GRC } \\
\end{array}$ & - & - & - & \\
\hline $\begin{array}{c}\text { Pelapis } \\
\text { Luar } \\
\text { GRC }\end{array}$ & 800 & 400 & 8 & 5,2 \\
\hline $\begin{array}{c}\text { Pelapis } \\
\text { Luar } \\
\text { GRC dan } \\
\text { Perkuatan } \\
\text { Wiremesh }\end{array}$ & 800 & 400 & 8 & 5,2 \\
\hline
\end{tabular}

Tabel 7. Berat panel dinding yang akan diuji

\begin{tabular}{|c|c|c|c|}
\hline $\begin{array}{l}\text { Variasi Panel } \\
\text { Dinding }\end{array}$ & $\begin{array}{c}\text { Berat } \\
\text { GRC (2 } \\
\text { GRC) } \\
(\mathrm{kg})\end{array}$ & $\begin{array}{c}\text { Berat Panel } \\
\text { Benda Uji } \\
\text { (kg) }\end{array}$ & $\begin{array}{l}\text { Berat } \\
\text { Panel } \\
\left(\mathbf{k g} / \mathbf{m}^{2}\right)\end{array}$ \\
\hline Tanpa Lapis GRC & - & 15,7 & 49.2 \\
\hline Pelapis Luar GRC & 5,2 & 15,9 & 49.7 \\
\hline $\begin{array}{c}\text { Pelapis Luar GRC } \\
\text { dan Perkuatan } \\
\text { Wiremesh }\end{array}$ & 5,2 & 15,9 & 49.7 \\
\hline
\end{tabular}

\section{Kuat Lentur Panel Dinding}

Pengujian kuat lentur panel dinding beton ringan busa dilakukan dengan menggunakan alat flexural strength. Terdapat 3 variasi panel dinding yang akan diuji. Hasil pengujian kuat lentur panel dinding dapat dilihat pada Tabel 8.

Tabel 8 Tegangan lentur panel dinding

\begin{tabular}{|c|c|}
\hline Variasi Panel Dinding & $\begin{array}{c}\text { Tegangan Lentur } \\
\text { (MPa) }\end{array}$ \\
\hline Tanpa Lapis GRC & 1,5 \\
\hline Pelapis Luar GRC & 4,6 \\
\hline $\begin{array}{c}\text { Pelapis Luar GRC dan } \\
\text { Perkuatan Wiremesh }\end{array}$ & 5,3 \\
\hline
\end{tabular}

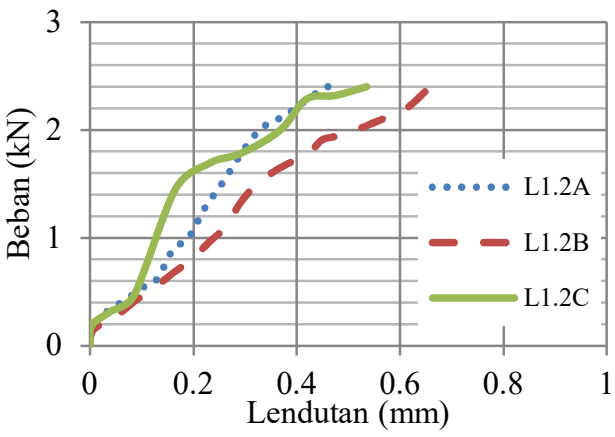

Gambar 8. Grafik uji lentur tanpa lapis (GRC)

Gambar 8 menunjukkan panel dinding tanpa perkuatan wiremesh dan tanpa lapis GRC memiliki karakteristik yang sama. Ketiga panel dinding bersifat getas, karena setelah mencapai beban maksimum panel dinding langsung mengalami patah. Pola keruntuhan panel dinding pada ketiga benda uji hampir sama. Pola keruntuhan panel dinding pada ketiga benda uji terletak pada tengah bentang panel dinding.

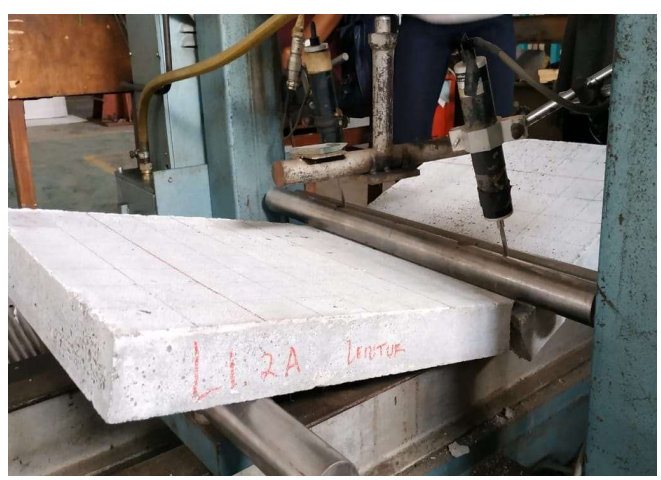

Gambar 9. Pola keruntuhan panel dinding tanpa lapis (GRC) 


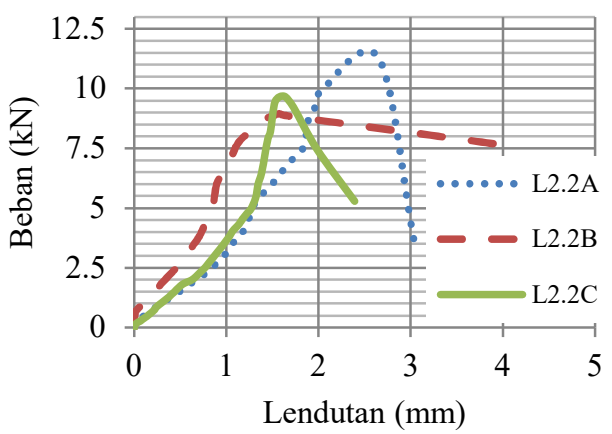

Gambar 10. Grafik uji lentur dengan pelapis luar (GRC)

Gambar 10 menunjukkan ketiga panel dinding bersifat getas, karena setelah mencapai beban maksimum panel dinding langsung mengalami patah. Pola keruntuhan yang terjadi pada pengujian ketiga panel dinding tersebut tidak tepat di tengah bentang panel dinding, pola keruntuhan hanya retakan-retakan yang terjadi pada pinggiran panel dinding. Hal ini dikarenakan adanya GRC pada sisi bagian atas dan bawah serta permukaan panel dinding yang dekat dengan tumpuan memiliki rongga udara yang lebih banyak, sehingga bagian tepi panel dinding lebih rapuh dibandingkan bagian tengah panel dinding.

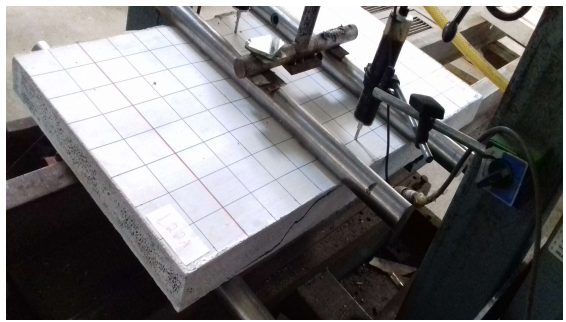

Gambar 11. Pola keruntuhan panel dinding dengan pelapis luar (GRC)

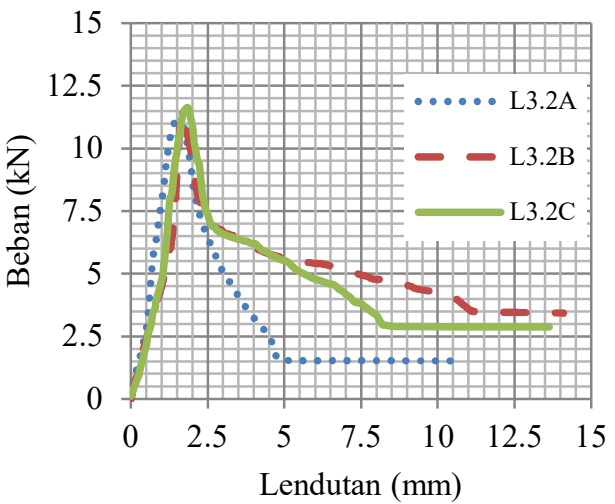

Gambar 12. Grafik uji lentur dengan pelapis luar (GRC) dan perkuatan wiremesh

Gambar 12 menunjukkan ketiga benda uji tersebut bersifat daktail. Hal ini dikarenakan setelah mencapai beban maksimum ketiga benda uji tersebut tidak langsung patah atau runtuh. Setelah mencapai maksimum, ketiga benda uji masih menahan beban yang terjadi seiring dengan bertambahnya lendutan. Hal ini dikarenakan adanya penambahan perkuatan wiremesh pada panel dinding. Ini membuktikan bahwa pemberian wiremesh pada panel dinding cukup efektif menjadikan panel dinding lebih daktail. Pola keruntuhan yang terjadi pada pengujian ketiga panel dinding tersebut tidak tepat di tengah bentang panel dinding, pola keruntuhan hanya retakan-retakan yang terjadi pada pinggiran panel dinding. Hal ini dikarenakan adanya GRC pada sisi bagian atas dan bawah serta permukaan panel dinding yang dekat dengan tumpuan memiliki rongga udara yang lebih banyak, sehingga bagian tepi panel dinding lebih rapuh dibandingkan bagian tengah panel dinding.

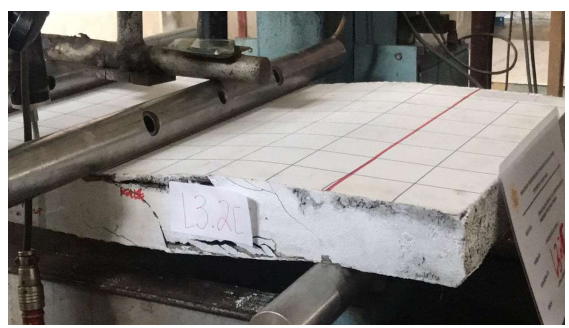

Gambar 13. Pola keruntuhan panel dinding dengan pelapis luar (GRC) dan perkuatan Wiremesh 


\section{Kuat Geser Panel Dinding}

Pengujian kuat geser panel dinding beton ringan dilakukan dengan cara pemberian beban terpusat di tengah bentang dengan posisi benda uji arah horizontal. Pengujian kuat geser untuk panel dinding sendiri belum ada standar pengujian yang mengatur mengenai pengujian kuat geser panel dinding. Pengujian bertujuan untuk mengetahui defleksi benda uji ketika mengalami suatu pembebanan. Terdapat 3 variasi panel dinding yang akan diuji. Ketiga variasi tersebut ada yang tidak diberikan pelapis luar GRC, ada yang diberikan pelapis luar GRC, dan yang terakhir diberikan pelapis luar GRC dan perkuatan wiremesh. Setiap variasi terdiri dari 3 benda uji panel dinding beton ringan.

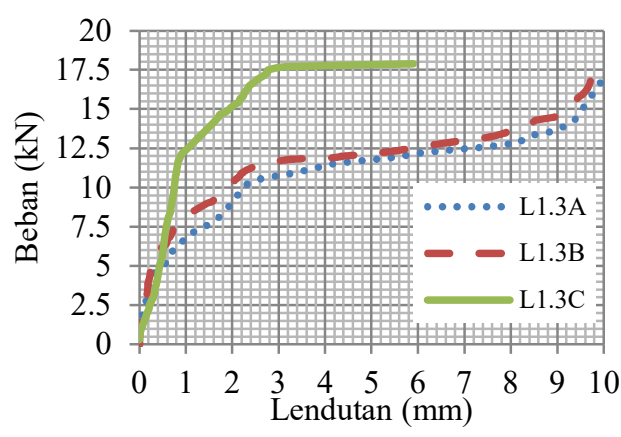

Gambar 14. Grafik uji geser tanpa lapis (GRC)

Panel dinding tanpa lapis GRC memiliki karakteristik yang sama. Ketiga panel dinding bersifat getas, karena setelah mencapai beban maksimum panel dinding langsung mengalami patah.

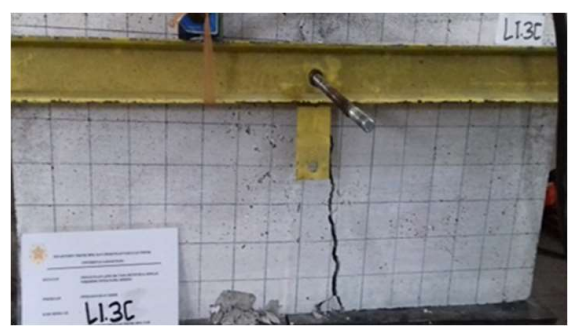

Gambar 15. Pola keruntuhan panel dinding

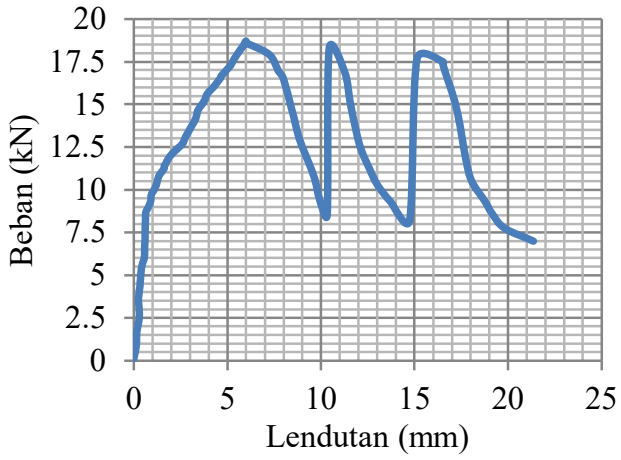

Gambar 16. Grafik uji geser dengan pelapis luar GRC (L2 (3A))

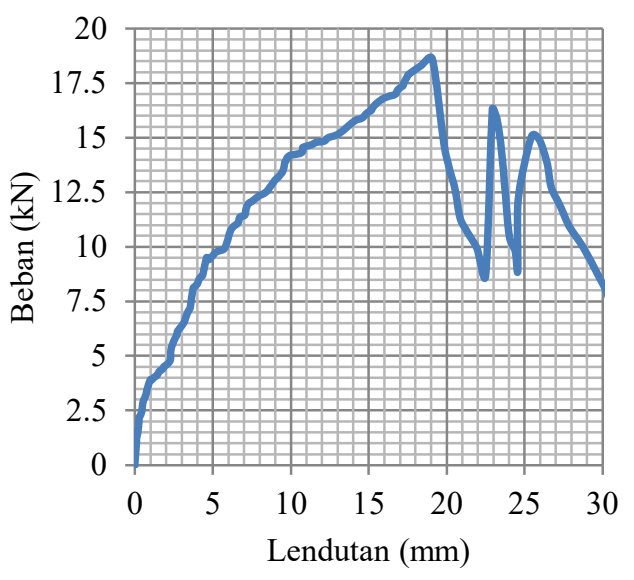

Gambar 17. Grafik uji geser dengan pelapis luar GRC (L2 (3B))

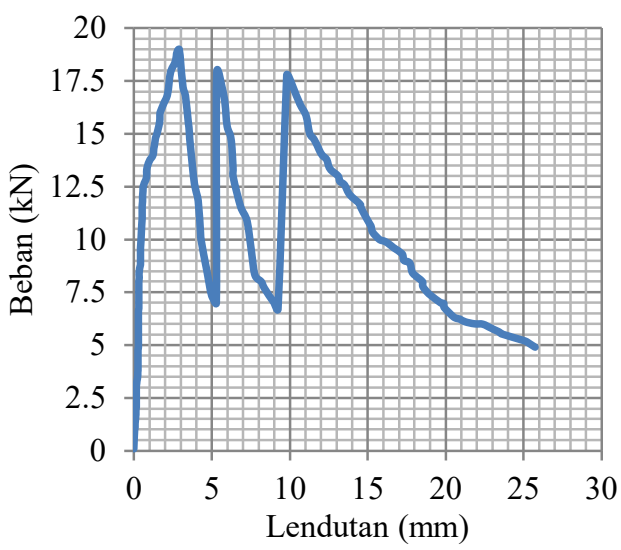

Gambar 18. Grafik uji geser dengan pelapis luar GRC (L2 (3C)) 
Gambar 16, Gambar 17, dan Gambar 18 menunjukkan ketiga benda uji tersebut bersifat daktail. Hal ini dikarenakan setelah mencapai beban maksimum ketiga benda uji tersebut tidak langsung patah atau runtuh, ini juga dikarenakan adanya pelapis luar GRC yang masih mampu menahan beban yang diberikan sehingga membuat hasil pada grafik terlihat mengalami kenaikan dan penurunan secara berulang-ulang dan diberhentikan ketika pejal sudah mencapai maksimum.

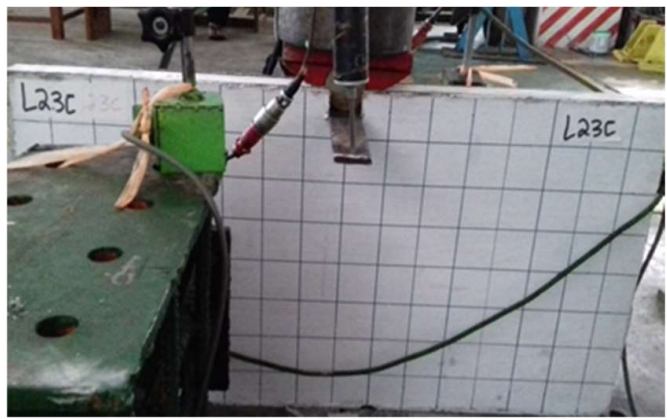

Gambar 19. Pola keruntuhan panel dinding

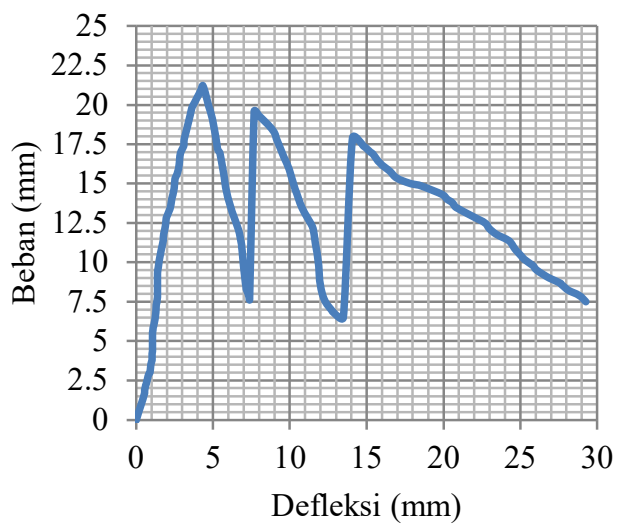

Gambar 20. Grafik uji geser dengan pelapis luar GRC dan perkuatan wiremesh (L3(3A))

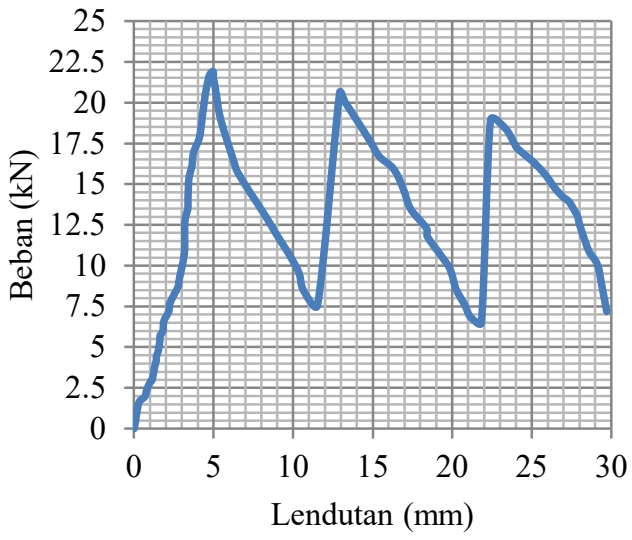

Gambar 21. Grafik uji geser dengan pelapis luar GRC dan perkuatan wiremesh (L3 (3B))

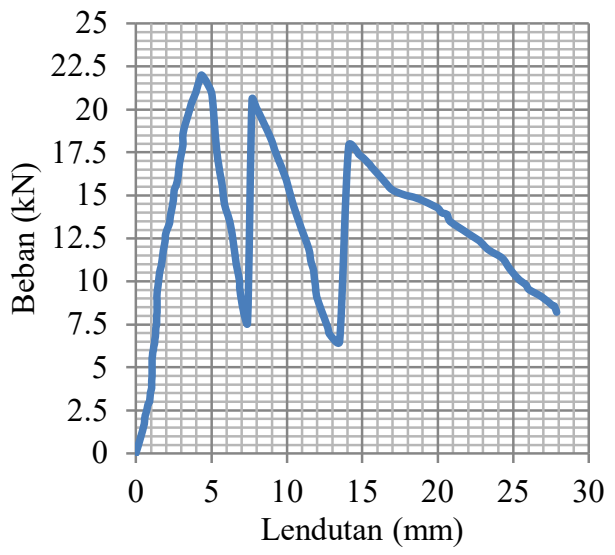

Gambar 22. Grafik uji geser dengan pelapis luar GRC dan perkuatan wiremesh (L3 (3C))

Gambar 20, Gambar 21, dan Gambar 22 menunjukkan ketiga benda uji tersebut bersifat daktail. Hal ini dikarenakan setelah mencapai beban maksimum ketiga benda uji tersebut tidak langsung patah atau runtuh. Setelah mencapai maksimum, ketiga benda uji masih menahan beban yang terjadi seiring dengan bertambahnya lendutan. Hal ini dikarenakan adanya penambahan pelapis luar GRC dan perkuatan wiremesh pada panel dinding. Pengujian diberhentikan ketika pejal sudah mencapai maksimum. 


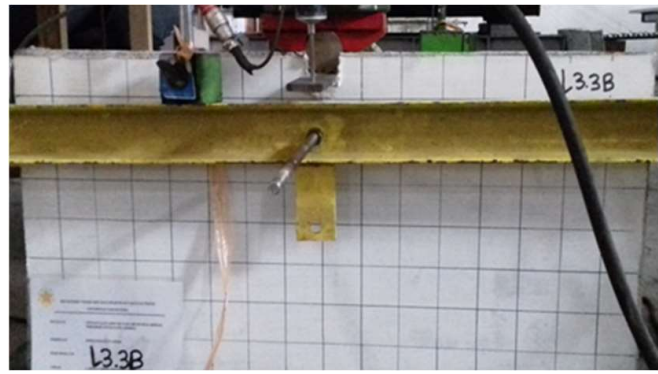

Gambar 23. Pola keruntuhan panel dinding

\section{KESIMPULAN}

Kuat tekan kubus beton ringan dengan ukuran $5 \mathrm{~cm} \times 5 \mathrm{~cm} \times 5 \mathrm{~cm}$ memperoleh rerata sebesar 5,2 $\mathrm{MPa}$ dan kuat tarik memperoleh rerata sebesar $0,7 \mathrm{MPa}$.

Modulus elastisitas beton ringan 6856,6 MPa.

Dari hasil analisa data yang dilakukan berdasarkan pengujian dalam penelitian ini, maka dapat diambil kesimpulan bahwa penggunaan lapis GRC dan perkuatan wiremesh dapat menambah kekuatan dari kuat lentur dan kuat geser panel dinding.

Nilai tegangan lentur panel dinding dengan menggunakan pelapis luar GRC dan perkuatan wiremesh juga memperoleh nilai yang jauh lebih besar bila dibandingkan dengan variasi lainnya yaitu sebesar 5,3 $\mathrm{MPa}$.

\section{DAFTAR PUSTAKA}

Abduh. (2007). "Teknologi Konstruksi Struktur Beton”. Jakarta: Erlangga.

ASTM C 307 - 03, (2003). "Standard Test Method for Tensile Strenght of Chemical-Resistant Mortar, Grout, and Monolithic Surfacings".

ASTM C 469 - 02. "Standard Test Method for Static Modulus of Elasticity and Poisson's Ratio of Concrete in Compression".
ASTM E 72 - 05. "Standard Test Method of Conducting Strength Tests of Panels for Building Construction".

ASTM E 72 - 98. "Standard Test Method of Conducting Strength Tests of Panels for Building Construction".

Chen Bing, Wu Zhen, dan Liu Ning, (2012). "Experimental Research on Properties of High-Strength Foamed Concrete". J. Mater. Civ. Eng., 2012, 24(1): 113-118.

CRD-C 260-01. "Standard Test Method for Tensile Strength of Hydraulic Cement Mortars".

Harnartyassanto. (2015). "Perilaku struktural panel dinding beton ringan campuran foam ekstrak klerak $50 \%$ dengan menggunakan perkuatan kawat loket". Tesis. Yogyakarta: Jurusan Teknik Sipil \& Lingkungan, Fakultas Teknik, Universitas Gadjah Mada.

Jhatial, (2018). "The mechanical properties of foamed concrete with polypropylene fibres". Master. Malaysia: Department of Structure and Materials, Faculty of Civil Engineering, University Technology Malaysia.

Mulyono, T, (2004). "Teknologi Beton", Penerbit C.V Andi Offset, Yogyakarta.

Neeladharan, (2018). "Flexural behaviour of lightweight concrete panel using Ferro cement". Master. India: Department of Civil Engineering, C. Abdul Hakeem College of Engineering and Technology.

Neville, A.M., and Brooks, J.J., (1987), "Concrete Technology, First Edition". Longman Scientific \& Technical, England.

Nugraha, P., Antoni, (2007). "Teknologi Beton". Penerbit Andi, Yogyakarta. 
Putra, (2017). "Panel dinding beton ringan foam dengan campuran abu batu dan perkuatan kawat loket". Tesis. Yogyakarta: Jurusan Teknik Sipil dan Lingkungan, Fakultas Teknik, Universitas Gadjah Mada.

Ratnasari, (2017). "Pengaruh perbandingan semen-pasir terhadap sifat beton busa sebagai material akustik". Tesis. Yogyakarta: Jurusan Teknik Sipil dan Lingkungan, Fakultas Teknik, Universitas Gadjah Mada.

Satyarno, I, (2015). "Perancangan Praktis Campuran Beton". Buku Ajar, Jurusan Teknik Sipil dan Lingkungan, Fakultas Teknik, Universitas Gadjah Mada, Yogyakarta.

Singer, L. F., dan Pytel, A., (1998). "Kekuatan Bahan (Teori Kokoh Strength of Materials)". Jakarta: Erlangga.

SK SNI S-04-1989-F, (1989). "Spesifikasi Bahan Bangunan Bagian A (Bahan Bangunan Bukan Logam)". Badan Standardisasi Nasional, Jakarta.

SNI 03-3122-1992. (1992). "Panel Beton Ringan Berserat". Jakarta: Badan Standardisasi Nasional.

SNI 03-6825-2002. (2002). "Metode Pengujian Kekuatan Mortar Semen Portland untuk Pekerjaan Sipil". Badan Standardisasi Nasional, Jakarta.

SNI 15-2049-2004. (2004). "Semen Portland". Badan Standardisasi Nasional, Jakarta.

Tjokrodimuljo, K, (2007). "Teknologi Beton”. Penerbit KMTS FT UGM, Yogyakarta. 